\title{
Physiological Responses of Beet and Cabbage Plants Exposed to Copper and their Potential Insertion in Human Food Chain
}

Odair J. Schmitt

Universidade Federal de Santa Maria

Jerônimo L. Andriolo

UFSM: Universidade Federal de Santa Maria

Isley C. B. Silva ( $\sim$ isleybicalho@yahoo.com.br)

Universidade Federal de Santa Maria Centro de Ciencias Rurais https://orcid.org/0000-0001-88012249

Tadeu L. Tiecher

IFRS: Instituto Federal de Educacao Ciencia e Tecnologia do Rio Grande do Sul

\section{Tatiane Chassot}

UFFS: Universidade Federal da Fronteira Sul

Camila Peligrinotti Tarouco

UFSM: Universidade Federal de Santa Maria

Cledimar Rogério Lourenzi

UFSC: Universidade Federal de Santa Catarina

Fernando Teixeira Nicoloso

UFSM: Universidade Federal de Santa Maria

Carina Marchezan

UFSM: Universidade Federal de Santa Maria

Cleiton Renato Casagrande

UFSM: Universidade Federal de Santa Maria

Gerson Laerson Drescher

UFSM: Universidade Federal de Santa Maria

Márcio André Kreutz

UFSM: Universidade Federal de Santa Maria

Gustavo Brunetto

UFSM: Universidade Federal de Santa Maria

\section{Research Article}

Keywords: Beta vulgaris L, Brassica oleracea cv. capitata, heavy metals, toxicity, vegetables 
Posted Date: July 26th, 2021

DOl: https://doi.org/10.21203/rs.3.rs-679984/v1

License: (c) (i) This work is licensed under a Creative Commons Attribution 4.0 International License. Read Full License

Version of Record: A version of this preprint was published at Environmental Science and Pollution Research on February 7th, 2022. See the published version at https://doi.org/10.1007/s11356-02218892-x. 


\section{Abstract}

Copper $(\mathrm{Cu})$ can be toxic to vegetables when it is absorbed and accumulated at large concentrations, a fact that increases the risk of excessive addition of this metal to the human food chain. The aims of the current study are (1) to determine the $\mathrm{Cu}$ concentrations that have critical toxic effects on beet and cabbage plants, and the potential of these plants to enter the human food chain; as well as (2) to assess the physiological and biochemical responses of representatives of these vegetables grown in nutrient solution presenting increasing $\mathrm{Cu}$ concentrations. Beet and cabbage plants were grown for 75 days in pots filled with sand added with nutrient solution presenting six Cu concentrations: $0.00,0.52,1.02,1.52$, 2.02 and $2.52 \mathrm{mg} \mathrm{Cu} \mathrm{L} \mathrm{-1.} \mathrm{Dry} \mathrm{matter} \mathrm{yield} \mathrm{and} \mathrm{Cu} \mathrm{accumulation} \mathrm{in} \mathrm{different} \mathrm{plant} \mathrm{organs} \mathrm{were}$ evaluated. Photosynthetic pigment contents, lipid peroxidation levels (TBARs), superoxide dismutase (SOD, EC 1.15.1.1) and peroxidase (POD, EC 1.11.1.7) activity, and hydrogen peroxide $\left(\mathrm{H}_{2} \mathrm{O}_{2}\right)$

concentrations in leaves were evaluated. Critical $\mathrm{Cu}$ concentrations that led to toxicity in plant organs such as beetroot and cabbage head, which are often found in human diets, corresponded to $1.43 \mathrm{mg} \mathrm{Cu} \mathrm{L}$ -1 and $1.59 \mathrm{mg} \mathrm{Cu} \mathrm{L}-1$, respectively. High Cu concentrations in the nutrient solution have increased $\mathrm{Cu}$ concentrations and accumulation in plant tissues. This outcome justified the increased POD and SOD enzyme activity in the leaves of beet and cabbage plants, respectively, as well as was the cause of reduced plant growth in both crops. Cabbage plants presented higher tolerance to increased Cu levels in the growing environment than beet plants. However, it is necessary being careful at the time to consume both vegetables, when they are grown in Cu-enriched environments.

\section{Introduction}

Copper $(\mathrm{Cu})$ is a heavy metal naturally found in the soil. Similar to other metals, total Cu concentrations depend on geological parent materials and on soil formation processes. In addition, anthropogenic activities such as mining, industrialization and agriculture can significantly contribute to increase $\mathrm{Cu}$ concentrations in the soil. $\mathrm{Cu}$ input in agricultural soils can increase due to the use of pesticides, bactericides and fungicides (Adrees et al., 2015; Brunetto et al., 2016; Miotto et al., 2017). In addition, the application of Cu-rich wastes, such as swine and poultry manure, can also help increasing Cu levels in the soil (De Conti et al., 2016; Yang et al., 2017). Sewage sludge and agroindustrial effluent deposition on the soil, as well as the use of wastewater for irrigation purposes, are well-known Cu sources (Belhaj et al., 2016).

Copper is essential to the growth and development of all living beings. However, excessive $\mathrm{Cu}$ concentration increase in agricultural soils is worrisome given its toxicity potential when it is absorbed by plants and animals at large amounts (Keller et al. 2015; Adrees et al. 2015). Thus, high Cu concentrations in crops focused on producing human and animal food such as grains, cereals, fruits and vegetables pose significant risks to food security.

Significantly decreased biomass production, reduced germination rates and number of leaves stand out among toxicity symptoms often observed in plants (Adrees et al., 2015; Trentin et al., 2019). Root 
systems undergo morphological and structural changes (Ambrosini et al., 2015; Lequeux et al., 2010) that lead to smaller soil surface exploration by plant roots and, consequently, to lower water and nutrient absorption (De Vos et al., 1989; Kopsell and Kopsell, 2007). Photosynthetic rates also decrease due to decreased levels of photosynthetic pigments such as chlorophyll and carotenoids (Bicalho da Silva et al., 2018; Cambrollé et al., 2015, 2013). In addition, excessive Cu concentrations in plant tissues can lead to oxidative stress and to cellular component degeneration. These processes result from imbalances between antioxidant reaction and increased generation of reactive oxygen species (ROS) in plants (Girotto et al., 2013).

Cu concentrations and accumulation in different plant organs, as well as their toxic effects on these organs, vary between plant species grown in vegetable crops (Cui et al., 2015; Pan et al., 2016). It happens due to differences in $\mathrm{Cu}$ absorption and translocation, which can be higher in leafy species that produce bulbs, roots and stems than in fructiferous plants (Ding et al., 2018; Hu et al., 2017). These differences may be mainly associated with barriers in $\mathrm{Cu}$ absorption and translocation by fruits (Sun et al., 2013). Variations in Cu concentrations in different organs of a single plant are usual. These concentrations can reach toxic levels in some organs and remain normal in others (Adrees et al., 2015). The effects of such variations on different plant species, as well as their tolerance mechanisms, change depending on the $\mathrm{Cu}$ concentrations in the tissue of different plant organs (Mateos-Naranjo et al., 2013).

Beetroot (Beta vulgaris L.) and cabbage (Brassica oleracea cv. capitata) stand out among the main olericulture species exploited in Brazil and abroad for trading purposes. These crops present different plant organs of commercial interest: tuberous roots in the beet culture and leaves forming the "head" in cabbage crops. Thus, these crops present different behaviors towards culture environments enriched with $\mathrm{Cu}$ and towards Cu contents observed in plant tissues (Ali et al., 2015; Morales et al., 2012). Based on the importance of these crops to human nutrition, it is essential investigating the tolerance of these vegetables to increased $\mathrm{Cu}$ levels in the culture medium, as well as the $\mathrm{Cu}$ distribution and concentration in plant organs, mainly in the ones used as human food. Based on such information, it is possible determining vegetable crops that can be grown in soil presenting increased Cu concentrations, but that do not lead to productivity loss or represent risks to human health.

The aims of the current study were (1) to determine critical Cu concentrations that could have toxic effects on beet and cabbage plants, as well as the potential of these plants to be added to the human food chain; and (2) to evaluate the physiological and biochemical responses of vegetables grown in nutrient solution presenting increasing $\mathrm{Cu}$ concentrations.

\section{Materials And Methods}

\subsection{Describing the experiments}

Two experiments were conducted for 75 days inside an umbrella-type container, which presented $65 \%$ ventilation surface and was covered with anti-UV additive polyethylene (100 $\mu \mathrm{m}$ thickness; $80 \%$ 
transmissivity). Mean air temperature and relative humidity in crop environment were measured in two electronic recorders (NOVUS, LogBox-RHT-LCD, Brazil), which were installed above the experiments results are shown in Figure 1.

Beet (cv. Katrina) and cabbage (cv. Fuyutoyio) plants were the vegetables assessed in the current study. Seedlings of both species were grown in polystyrene trays filled with coconut fiber-based granulated substrate (Golden Mix ${ }^{\circledR}$ ) - 30-day-old seedlings were transplanted to experimental units.

Both experiments followed a completely randomized experimental design, with 6 treatments $(0.00 ; 0.52$; $1.02 ; 1.52 ; 2.02$ and $\left.2.52 \mathrm{mg} \mathrm{Cu} \mathrm{L}^{-1}\right)$ and 5 repetitions, which resulted in 30 experimental units per experiment, in total. Experimental units consisted in polypropylene pots (volume $=2.5 \mathrm{dm}^{3}$ ) filled with sand (particle size ranged from 1 to $3 \mathrm{~mm}$ ); their maximum water-holding capacity was $0.24 \mathrm{~L} \mathrm{dm}^{-3}$; each pot had 1 plant.

Water and nutrients were supplied to the plants through fertigation, based on dripping tapes (one dripper per pot), throughout the experimental period. Nutrient solution was prepared and stored in $500 \mathrm{~L}$ polypropylene boxes; a motor pump controlled by a time scheduler was used to supply plants with the solution. Fertigation frequency was determined based on the intensity of global solar radiation and on the potential transpiration of locally grown vegetables (Tazzo et al., 2012) by taking into consideration $30 \%$ drainage coefficient. Three to five 15-minute-long fertigations were performed on a daily basis. The volume of drained nutrient solution returned to the nutrient solution storage box to be reused in a closed system. Electrical conductivity $(E C)$ and nutrient solution $\mathrm{pH}$ were measured every day. Whenever the measured EC value recorded $5 \%$ deviation from the reference value $\left(1.5 \mathrm{dS} \mathrm{m}^{-1}\right)$, it was corrected through the addition of water or aliquots of new nutrient solution at reference concentrations; $\mathrm{NaOH}\left(1 \mathrm{~mol} \mathrm{~L}^{-1}\right)$ and $\mathrm{H}_{2} \mathrm{SO}_{4}\left(0.5 \mathrm{~mol} \mathrm{~L}^{-1}\right)$ were added to the nutrient solution in order to increase and reduce its $\mathrm{pH}$ value, respectively, in order to kept it between 5.5 and 6.0.

The chemical composition of the water used to prepare the nutrient solutions did not show $\mathrm{Cu}$ concentration up to limit of $0.04 \mathrm{mg} \mathrm{L}^{-1}$ (Standard Methods $3111 \mathrm{~B}$ ). The same nutrient solution was used in all treatments, except for $\mathrm{Cu}$. Macronutrient concentrations were $12.24 \mathrm{mmol}$ of $\mathrm{L}^{-1}$ of $\mathrm{NO}_{3}{ }^{-}, 3.0$ $\mathrm{mmol} \mathrm{L}^{-1}$ of $\mathrm{NH}_{4}{ }^{+}, 2.5 \mathrm{mmol} \mathrm{L}^{-1}$ of $\mathrm{H}_{2} \mathrm{PO}_{4}^{-}, 6.5 \mathrm{mmol} \mathrm{L}^{-1}$ of $\mathrm{K}^{+}, 2.62 \mathrm{mmol} \mathrm{L}^{-1}$ of $\mathrm{Ca}^{+2}$ and $2.0 \mathrm{mmol} \mathrm{L}^{-1}$ of $\mathrm{Mg}^{+2}$. Micronutrient concentrations were $0.03 \mathrm{mg} \mathrm{L}^{-1}$ of $\mathrm{Mo}, 0.26 \mathrm{mg} \mathrm{L}^{-1}$ of $\mathrm{B}, 0.50 \mathrm{mg} \mathrm{L}^{-1}$ of $\mathrm{Mn}, 0.22 \mathrm{mg}$ $\mathrm{L}^{-1}$ of $\mathrm{Zn}$ and $1.0 \mathrm{mg} \mathrm{L}^{-1}$ of Fe through stock solution. Fe was individually supplied in its chelated form (EDDHA). The nutrient solution presented electrical conductivity (EC) equal to $1.5 \mathrm{dS} \mathrm{m}^{-1}$ and pH 5.8. Macronutrient sources comprised fertilizers such as potassium nitrate $\left(\mathrm{KNO}_{3}\right)$, monoammonium phosphate $\left(\mathrm{NH}_{4} \mathrm{H}_{2} \mathrm{PO}_{4}\right)$, calcium-Calcinit ${ }^{\circledR}$ nitrate $\left(\mathrm{Ca}\left(\mathrm{NO}_{3}\right)_{2}\right)$ and magnesium sulfate $\left(\mathrm{MgSO}_{4}\right)$.

\subsection{Photosynthetic pigments}


Three plants from each treatment were randomly selected 72 days after transplantation. Three freshly expanded leaves from each beet plant, as well as three leaves from the middle third of the plant, which were not yet part of the head of each cabbage plant, were collected. Leaves were frozen in liquid $\mathrm{N}_{2}$ and stored in ultra-freezer (Indrel, RVV $880 \mathrm{D}$, Brazil) at $-80^{\circ} \mathrm{C}$, right after collection. Chlorophyll $a$, chlorophyll $b$ and carotenoid extraction was carried out in $0.05 \mathrm{~g}$ of leaf limb, based on the methodology by Hiscox \& Israelstam (1979). Extract absorbance was analyzed in spectrophotometer (FEMTO, Spectrophotometer $800 \mathrm{XI}$, Brazil) and recorded $663 \mathrm{~nm}$ for chlorophyll $a, 645 \mathrm{~nm}$ for chlorophyll $b$ and $470 \mathrm{~nm}$ for carotenoids. Pigment content was calculated based on the methodology by Lichtenthaler (1987). Total chlorophyll (the sum of chlorophyll $a$ and chlorophyll $b$ contents), as well as chlorophyll $a$ /chlorophyll $b$ and carotenoids/total chlorophyll ratios were calculated based on photosynthetic pigment contents.

\subsection{Biochemical analyses}

Malondialdehyde (MDA) concentration - thiobarbituric acid reactive substance (TBARS) - was indirectly determined based on the lipid peroxidation level, according to the methodology described by El-moshaty et al. (1993); subsequently, it was determined at $532 \mathrm{~nm}$ and $600 \mathrm{~nm}$ in spectrophotometer (FEMTO, Spectrophotometer $800 \mathrm{XI}$, Brazil). In order to determine enzymes such as superoxide dismutase (SOD, EC 1.15.1.1) and peroxidases (POD, EC 1.11.1.7), the enzyme extract was obtained from $0.5 \mathrm{~g}$ of fresh leaf tissue, which was macerated with liquid $\mathrm{N}_{2}$ and homogenized with $3.0 \mathrm{~mL}$ of $50 \mathrm{mM}$ sodium phosphate buffer (NaPB - pH 7.8) containing 1.0 mM EDTA, and 0.5\% Triton X-100 (v / v). The extract was centrifuged at $13,000 \mathrm{~g}$ for 20 minutes at $4^{\circ} \mathrm{C}$ and the supernatant was collected (Zhu et al., 2004). Next, $0.5 \mathrm{~mL}$ aliquots of it were stored in freezer at $-80^{\circ} \mathrm{C}$, until enzyme quantification. SOD enzyme activity was determined based on the spectrophotometric method described by Giannopolitis \& Ries (1977). POD enzyme activity in the extract was determined based on Zeraik et al. (2008), whereas hydrogen peroxide $\left(\mathrm{H}_{2} \mathrm{O}_{2}\right)$ content was determined based on the method described by Loreto \& Velikova (2001).

\subsection{Fresh and dry mass production and critical toxicity concentrations}

Plant harvesting point was identified at the $75^{\text {th }}$ cultivation day (Filgueira, 2012). The harvesting point of beet plants was based on the mean diameter $(8.5 \mathrm{~cm})$ of tuberous roots from 5 plants subjected to the treatment that enabled the highest plant growth. Similarly, the harvesting point of cabbage plants was based on head compactness at the onset of fully developed basal leaf senescence. The shoot of each plant was initially collected and weighed in a $0.01 \mathrm{~g}$ precision scale (Shimadzu, BL $3200 \mathrm{H}, \mathrm{Brazil}$ ) in order to determine shoot (SFM) and tuberous root (TRFM) fresh mass in beet plants, as well as fresh head mass (HFM) in cabbage plants. Collected plants were divided into different parts; beet plants were divided into leaves, petioles, tuberous root and roots, whereas cabbage plants were divided into leaves, head, stem and roots. Samples were dried in forced-air oven at $65^{\circ} \mathrm{C}$, until they reached constant mass in order to determine the dry mass of each plant organ. Subsequently, a $0.001 \mathrm{~g}$ precision scale (Marconi, 
MABL500C, Brazil) was used to determine the dry mass of leaves (LDM), petioles (PDM), tuberous root (TRDM) and roots (RDM) of beet plants, as well as the dry mass of leaves that did not form the head (LDM), head leaves (HDM), stem (StDM) and roots (RDM) in cabbage plants. Total shoot dry mass (SDM) was determined by summing the DM of the corresponding organs. The critical toxicity concentration (CCT), which represents the Cu concentration capable of decreasing DM production by $10 \%$, as well as toxic concentrations TC25 and TC50, which decrease DM production of each organ by $25 \%$ and $50 \%$, respectively, were calculated based on the methodology by Davis et al. (1978).

\subsection{Cu concentration and accumulation in plants}

The dry matter of leaves, petioles, tuberous root and roots of beet plants, as well as the dry matter of leaves that did not form the head, head, stem and roots of cabbage plants, were ground in Willey-type mill, sieved (20 mesh) and subjected to nitro-perchloric digestion (Embrapa, 2009). Atomic absorption spectrophotometer (Perkin Elmer, Aanalyst 200, USA) was used to determine the Cu content in each organ based on their respective extracts. Subsequently, $\mathrm{Cu}$ accumulated in each organ and total $\mathrm{Cu}$ accumulated per plant were calculated.

\subsection{Statistical analysis}

Data normality assumption was tested and found through the Kolmogorov-Smirnov test and, subsequently, analysis of variance was performed. Regression equations were adjusted by testing linear and quadratic models in the $F$ test, in case of significant treatment effects $(p \leq 0.05)$. The model presenting significance higher than $95 \%$ in the ASSISTAT software version 7.7 was the chosen one. Mean value was calculated whenever there was not significant difference between means in each treatment.

\section{Results}

\subsection{Growth parameters and critical Cu toxicity concentrations}

Shoot (SFM) and tuberous root (TRFM) fresh mass, as well as leaf (LDM), petiole (PDM), tuberous root (TRDM) and root (RDM) dry mass of beet plants decreased as Cu concentrations increased in the nutrient solution (Table 1). Beet plants grown in soil subjected to the highest Cu concentration (2.52 $\left.\mathrm{mg} \mathrm{L}^{-1}\right)$ recorded SFM, TRFM, LDM, PDM and SDM decrease by 55\%, 52\%, 56\%, 60\% and 57\%, respectively, in comparison to beet plants grown in soil subjected to the lowest $\mathrm{Cu}$ concentration $\left(0.0 \mathrm{mg} \mathrm{L}^{-1}\right)$, as shown in Figures $2 \mathrm{a}, \mathrm{b}$ and $\mathrm{c}$. The shoot/root dry mass production ratio (TRDM + RDM) decreased from 0.62 in the Cu-free treatment to 0.41 in the treatment comprising $\mathrm{Cu}$ concentration of $2.52 \mathrm{mg} \mathrm{L}^{-1}$ in the nutrient solution. 


\section{Table 1}

Growth parameters, photosynthetic pigments, accumulated $\mathrm{Cu}$ contents and biochemical parameters in beet plants belonging to cultivar "Katrina", grown in nutrient solution presenting different $\mathrm{Cu}$ concentrations. 


\begin{tabular}{|c|c|c|c|c|}
\hline Evaluated parameters & Significance & Adjusted Equation/Mean & $\mathrm{R}^{2}$ & $\mathrm{CV}(\%)$ \\
\hline \multicolumn{5}{|l|}{ Growth parameters } \\
\hline SFM & * & $\hat{y}=628.40-20.125 x-46.839 x^{2}$ & 0.95 & 18.26 \\
\hline TRFM & * & $\hat{y}=400.53-9.870 x-29.133 x^{2}$ & 0.98 & 20.60 \\
\hline SDM & * & $\hat{y}=19.995-0.870 x-1.460 x^{2}$ & 0.83 & 26.27 \\
\hline LDM & * & $\hat{y}=12.250+0.130 x-1.137 x^{2}$ & 0.77 & 25.21 \\
\hline PDM & * & $\hat{y}=7.671-0.674 x-0.467 x^{2}$ & 0.92 & 31.11 \\
\hline TRDM & * & $\hat{y}=30.402+0.436 x-1.799 x^{2}$ & 0.99 & 11.01 \\
\hline RDM & * & $\hat{y}=1.607-0.079 x-0.144 x^{2}$ & 0.88 & 23.09 \\
\hline \multicolumn{5}{|l|}{ Cu concentrations } \\
\hline Leaves & ** & $\hat{y}=7.17+49.99 x-12.06 x^{2}$ & 0.98 & 3.87 \\
\hline Petioles & ** & $\hat{y}=10.02+15.60 x-2.75 x^{2}$ & 0.97 & 8.66 \\
\hline Tuberous roots & ** & $\hat{y}=12.10+44.42 x-12.82 x^{2}$ & 0.99 & 3.54 \\
\hline Roots & ** & $\hat{y}=52.31+1.095 .51 x-228.55 x^{2}$ & 0.91 & 12.23 \\
\hline \multicolumn{5}{|l|}{ Accumulated $\mathrm{Cu}$} \\
\hline Leaves & ** & $\hat{y}=0.13+0.53 x-0.18 x^{2}$ & 0.97 & 24.51 \\
\hline Petioles & ns & 0.123 & & 34.82 \\
\hline Tuberous roots & ** & $\hat{y}=0.38+1.33 x-0.46 x^{2}$ & 0.97 & 11.06 \\
\hline Roots & ** & $\hat{y}=0.01+1.46 x-0.47 x^{2}$ & 0.93 & 27.88 \\
\hline Total & ** & $\hat{y}=0.60+3.41 x-1.14 x^{2}$ & 0.98 & 15.56 \\
\hline \multicolumn{5}{|l|}{ Photosynthetic Pigments } \\
\hline Chlorophyll a & ns & 0.836 & & 23.10 \\
\hline Chlorophyll $b$ & ns & 0.459 & & 25.86 \\
\hline Carotenoids & ns & 0.267 & & 23.45 \\
\hline Total chlorophyll & ns & 1.295 & & 23.94 \\
\hline Chlorophyll $a$ / Chlorophyll $b$ & ns & 1.821 & & 5.65 \\
\hline Carotenoids/Total Chlorophyll & ns & 0.206 & & 3.45 \\
\hline
\end{tabular}




\begin{tabular}{|c|c|c|c|c|}
\hline \multicolumn{5}{|c|}{ Biochemical parameters } \\
\hline Tbars & ns & 1.045 & & 27.83 \\
\hline SOD & ns & 11.367 & & 39.77 \\
\hline POD & ** & $\hat{y}=0.21+0.24 x+0.003 x^{2}$ & 0.91 & 29.69 \\
\hline $\mathrm{H}_{2} \mathrm{O}_{2}$ & ns & 0.846 & & 21.73 \\
\hline
\end{tabular}

Growth variables such as StDM and RDM in the cabbage crop did not show differences between treatments applied to the nutrient solution. Variables such as SFM, HFM, SDM, LDM and HDM decreased as $\mathrm{Cu}$ concentrations increased in the nutrient solution (Table 2); such decrease corresponded to $30 \%$, $47 \%, 16 \%, 19 \%$ and $28 \%$, respectively, in the comparison between the Cu-free treatment and the one comprising the highest Cu concentration (Figures $2 \mathrm{a}, \mathrm{b}, \mathrm{c}$ ).

Table 2

Growth parameters, photosynthetic pigments, accumulated $\mathrm{Cu}$ contents and biochemical parameters in cabbage plants (cv. "Fuyutoyo") grown in nutrient solution presenting different Cu concentrations. 


\begin{tabular}{|c|c|c|c|c|}
\hline Evaluated parameters & Significance & Adjusted Equation/Mean & $\mathrm{R}^{2}$ & CV (\%) \\
\hline \multicolumn{5}{|l|}{ Growth parameters } \\
\hline SFM & $\star *$ & $\hat{y}=2.558 .94-73.02 x-95.07 x^{2}$ & 0.98 & 13.52 \\
\hline HFM & $\star \star$ & $\hat{y}=1.141 .97-192.34 x-9.22 x^{2}$ & 0.88 & 12.16 \\
\hline SDM & $\star \star$ & $\hat{y}=197.47-11.48 x-2.03 x^{2}$ & 0.90 & 7.32 \\
\hline LDM & ** & $\hat{y}=117.77-13.69 x+1.80 x^{2}$ & 0.92 & 9.46 \\
\hline HFM & $\star \star$ & $\hat{y}=62.58+1.47 x-3.40 x^{2}$ & 0.83 & 11.99 \\
\hline StDM & ns & 11.30 & & 8.60 \\
\hline RDM & ns & 17.04 & & 14.25 \\
\hline \multicolumn{5}{|l|}{ Cu concentrations } \\
\hline Leaves & $\star \star$ & $\hat{y}=13.80+17.69 x-1.92 x^{2}$ & 0.97 & 6.99 \\
\hline Head & ** & $\hat{y}=23.91+3.02 x+1.69 x^{2}$ & 0.96 & 5.97 \\
\hline Stem & $\star \star$ & $\hat{y}=10.20+60.22 x-17.15 x^{2}$ & 0.96 & 9.50 \\
\hline Roots & $\star \star$ & $\hat{y}=26.48+482.07 x-38.70 x^{2}$ & 0.97 & 8.17 \\
\hline \multicolumn{5}{|l|}{ Accumulated $\mathrm{Cu}$} \\
\hline Leaves & $\star *$ & $\hat{y}=1.69+1.61 x-0.21 x^{2}$ & 0.97 & 12.27 \\
\hline Head & ns & 1.747 & & 13.33 \\
\hline Stem & ** & $\hat{y}=0.16+1.10 x-0.32 x^{2}$ & 0.98 & 14.18 \\
\hline Roots & ** & $\hat{y}=0.17+5.90 x-0.67 x^{2}$ & 0.96 & 23.37 \\
\hline Total & $\star \star$ & $\hat{y}=3.52+8.87 x-1.24 x^{2}$ & 0.97 & 14.97 \\
\hline \multicolumn{5}{|l|}{ Photosynthetic Pigments } \\
\hline Chlorophyll a & ns & 0.779 & & 16.25 \\
\hline Chlorophyll $b$ & ns & 0.463 & & 17.26 \\
\hline Carotenoids & ns & 0.254 & & 21.22 \\
\hline Total chlorophyll & ns & 1.242 & & 14.37 \\
\hline Chlorophyll a/ Chlorophyll $b$ & * & s. a (0.193) & & 6.10 \\
\hline Carotenoids /Total chlorophyll & * & $\hat{y}=0.21-0.03 x+0.01 x^{2}$ & 0.84 & 3.45 \\
\hline
\end{tabular}


Biochemical parameters

\begin{tabular}{lllll|} 
Tbars & ns & 0.836 & 28.86 \\
\hline SOD & $* *$ & $\hat{y}=6.97-0.83 x+1.71 x^{2}$ & 0.66 & 15.58 \\
POD & $n s$ & 4.828 & 36.13 \\
$\mathrm{H}_{2} \mathrm{O}_{2}$ & ns & 0.394 & 12.99 \\
$\begin{array}{l}\text { Significance in the F Test: } n s=\text { non-significant; * } \\
\text { mathematical adjustment up to } 2^{\text {nd }} \text { degree. }\end{array}$
\end{tabular}

There was difference in Cu concentrations necessary to reduce SDM production in the nutrient solution by $10 \%$ (CTC) and $25 \%\left(\mathrm{TC}_{25}\right)$ between the two assessed vegetables (Table 3). CTC and $\mathrm{TC}_{25}$ in the shoot were $54.9 \%$ and $50 \%$ higher in cabbage than in beet plants. Organs often consumed in human diets, such as tuberous beetroot and cabbage head, recorded CTC corresponding to $1.43 \mathrm{mg} \mathrm{Cu} \mathrm{L}^{-1}$ and $1.59 \mathrm{mg} \mathrm{Cu}$ $\mathrm{L}^{-1}$, respectively. Cu concentrations required to reduce leaf, petiole, root and shoot dry mass production by $50 \%\left(\mathrm{TC}_{50}\right)$ in beet plants were $2.38 \mathrm{mg} \mathrm{Cu} \mathrm{L}^{-1}, 2.24 \mathrm{mg} \mathrm{Cu} \mathrm{L}^{-1}, 2.10 \mathrm{mg} \mathrm{Cu} \mathrm{L}^{-1}$ and $2.33 \mathrm{mg} \mathrm{Cu} \mathrm{L}^{-1}$, respectively. On the other hand, $\mathrm{TC}_{50}$ was not recorded for any of the assessed variables in the cabbage crop or for tuberous roots in the beet crop.

Table 3

Critical Cu toxicity concentrations recorded for beet (cv. Katrina) and cabbage (cv. Fuyutoyo) plants grown in nutrient solution presenting different $\mathrm{Cu}$ concentrations.

\begin{tabular}{|c|c|c|c|c|c|c|c|c|}
\hline \multirow{2}{*}{$\begin{array}{l}\text { Critical } \\
\text { concentrations }\end{array}$} & \multicolumn{5}{|c|}{ Beet plant } & \multicolumn{3}{|c|}{ Cabbage plant } \\
\hline & Leaves & Petioles & $\begin{array}{l}\text { Tuberous } \\
\text { roots }\end{array}$ & Roots & Shoot & Leaves & Head & Shoot \\
\hline & \multicolumn{8}{|c|}{$\mathrm{Cu}\left(\mathrm{mg} \mathrm{L}^{-1}\right)$} \\
\hline CTC $^{1}$ & 1.10 & 0.76 & 1.43 & 0.82 & 0.91 & 1.0 & 1.59 & 1.41 \\
\hline $\mathrm{TC}_{25}{ }^{2}$ & 1.70 & 1.43 & 2.18 & 1.42 & 1.58 & n. a & n. a & 2.37 \\
\hline $\mathrm{TC}_{50}^{3}$ & 2.38 & 2.24 & n. a & 2.10 & 2.33 & n. a & n. a & n. a \\
\hline \multicolumn{9}{|c|}{ 1. Cu concentration in the solution required to inhibit dry matter by $10 \%$; } \\
\hline \multicolumn{9}{|c|}{ 2. Cu concentration in the solution required to inhibit dry matter by $25 \%$. } \\
\hline \multicolumn{9}{|c|}{ 3. Cu concentration in the solution required to inhibit dry matter by $50 \%$. } \\
\hline n. $a=$ concentra & n was no & achieved. & & & & & & \\
\hline
\end{tabular}




\subsection{Cu concentrations and accumulation in plant organs}

$\mathrm{Cu}$ concentrations in beet leaves, petioles, tuberous root and roots increased as $\mathrm{Cu}$ concentrations in the nutrient solution increased (Table 1; Figures $2 \mathrm{~d}$ and e). They reached maximum values at copper concentrations adjusted to $2.07 \mathrm{mg} \mathrm{Cu} \mathrm{L}^{-1}, 2.52 \mathrm{mg} \mathrm{Cu} \mathrm{L}^{-1}, 1.73 \mathrm{mg} \mathrm{Cu} \mathrm{L}^{-1}$ and $2.40 \mathrm{mg} \mathrm{Cu} \mathrm{L}^{-1}$ in the nutrient solution, respectively. Maximum $\mathrm{Cu}$ concentrations in beet leaves, petiole, tuberous root and roots corresponded to $59.0 \mathrm{mg} \mathrm{Cu} \mathrm{kg}^{-1}, 31.9 \mathrm{mg} \mathrm{Cu} \mathrm{kg}^{-1}, 50.6 \mathrm{mg} \mathrm{Cu} \mathrm{kg}^{-1}$ and 1,365.1 mg Cu kg${ }^{-1}$, respectively. These concentrations represented $\mathrm{Cu}$ increase by $722 \%$ (leaves), 218\% (petioles), 318\% (tuberous root) and $2,509 \%$ (roots) in comparison to the same organs of beet plants grown in nutrient solution subjected to the Cu-free treatment.

The highest total $\mathrm{Cu}$ accumulation in beet plants was recorded when they received nutrient solution containing $1.5 \mathrm{mg} \mathrm{Cu} \mathrm{L}^{-1}$. This accumulation value was $425 \%$ higher than the one recorded for beet plants that were not exposed to Cu via nutrient solution. On the other hand, beet plants grown in nutrient solution subjected to $\mathrm{Cu}$ concentrations higher than $1.5 \mathrm{mg} \mathrm{L}^{-1}$ recorded total $\mathrm{Cu}$ accumulation decrease by $38.1 \%$ at the highest $\mathrm{Cu}$ concentration.

Cu concentrations in the leaves, head, stem and roots of cabbage plants recorded quadratic increase (Table 2; Figures $3 \mathrm{~d}$ and e). These organs reached maximum dry mass values equal to $46.2 \mathrm{Cu} \mathrm{kg}^{-1}, 42.2$ $\mathrm{Cu} \mathrm{kg}{ }^{-1}, 63.1 \mathrm{Cu} \mathrm{kg}^{-1}$ and $995.5 \mathrm{mg} \mathrm{Cu} \mathrm{kg}^{-1}$, respectively. These concentrations were recorded for leaves, head and roots when plants were grown in nutrient solution subjected to the highest Cu concentration ( $2.52 \mathrm{mg} \mathrm{Cu} \mathrm{L}^{-1}$ ). The highest $\mathrm{Cu}$ concentration in stem tissue was found in plants grown in nutrient solution subjected to $1.75 \mathrm{mg} \mathrm{Cu} \mathrm{L}^{-1}$. Maximum Cu concentrations in cabbage leaves, head, stem and roots increased by $234 \%, 76 \%, 518 \%$ and $3,659 \%$, respectively, in comparison to the same organs of plants subjected to the Cu-free treatment $\left(0.0 \mathrm{mg} \mathrm{Cu} \mathrm{L}^{-1}\right)$.

$\mathrm{Cu}$ accumulated in cabbage organs, except for the head, increased as $\mathrm{Cu}$ concentrations in the nutrient solution increased (Table 2; Figure $3 \mathrm{f}$ ). The highest $\mathrm{Cu}$ accumulation in the leaves and roots, as well as the total $\mathrm{Cu}$ accumulation in cabbage plants, were observed after the application of nutrient solution added with $2.52 \mathrm{mg} \mathrm{Cu} \mathrm{L}^{-1}$. Cabbage plants subjected to this treatment accumulated $4.4 \mathrm{~g}$ of $\mathrm{Cu}$ in leaves, $10.8 \mathrm{~g}$ of $\mathrm{Cu}$ in roots, and $18.0 \mathrm{~g}$ of $\mathrm{Cu}$ in the whole plant; these contents corresponded to $\mathrm{Cu}$ increase by $161 \%, 6,242 \%$ and $411 \%$ in the same organs, respectively, in comparison to the one recorded for plants grown in Cu-free nutrient solution. Cabbage stem recorded the highest $\mathrm{Cu}$ content $(1.1 \mathrm{~g} \mathrm{Cu}$ plant $^{-1}$ ) at Cu concentration $1.72 \mathrm{mg} \mathrm{L}^{-1}$.

\subsection{Photosynthetic pigments and biochemical parameters}


Chlorophyll $a$, chlorophyll $b$, carotenoid and total chlorophyll contents in the leaves of beet and cabbage plants did not differ between Cu concentrations in the nutrient solution (Tables 1 and 2). Mean chlorophyll $a$, chlorophyll $b$, carotenoid and total chlorophyll levels in the leaves of beet plants recorded $0.836 \mathrm{mg} \mathrm{g}^{-1}, 0.459 \mathrm{mg} \mathrm{g}^{-1}, 0.267 \mathrm{mg} \mathrm{g}^{-1}$ and $1.295 \mathrm{mg} \mathrm{g}^{-1}$ of leaf fresh mass (Table 1). Chlorophyll $a$, chlorophyll $b$, carotenoid and total chlorophyll contents in cabbage leaves recorded $0.799 \mathrm{mg} \mathrm{g}^{-1}, 0.463$ $\mathrm{mg} \mathrm{g}^{-1}, 0.254 \mathrm{mg} \mathrm{g}^{-1}$ and $1.242 \mathrm{mg} \mathrm{g}^{-1}$ of leaf fresh mass, respectively (Table 2). Chlorophyll $\mathrm{a} /$ chlorophyll $\mathrm{b}$ and carotenoids/total chlorophyll ratios in beet plants did not differ from each other between $\mathrm{Cu}$ concentrations (Table 1). Chlorophyll a/chlorophyll b and carotenoids/total chlorophyll ratios in cabbage plants differed from each other between Cu concentrations (Table 2). However, only carotenoids/total chlorophyll ratio was higher in the leaves of plants grown in Cu-free nutrient solution.

Mean POD activity values in the leaves of beet plants differed from each other and increased as $\mathrm{Cu}$ concentrations in the nutrient solution increased; minimum and maximum values were observed at $\mathrm{Cu}$ concentrations $0.0 \mathrm{mg} \mathrm{L}^{-1}$ and $2.52 \mathrm{mg} \mathrm{L}^{-1}$, respectively. Means recorded for TBARs levels, SOD activity and $\mathrm{H}_{2} \mathrm{O}_{2}$ concentration in the leaves of plants grown at different $\mathrm{Cu}$ concentrations did not differ from each other (Table 1).

SOD activity in cabbage leaves increased as Cu concentrations in the nutrient solution increased (Table 2). Maximum SOD activity was observed at the highest $\mathrm{Cu}$ concentration in the nutrient solution $(2.52 \mathrm{mg}$ $\mathrm{Cu} \mathrm{L}{ }^{-1}$ ). TBAR levels, POD activity and $\mathrm{H}_{2} \mathrm{O}_{2}$ concentrations did not respond to $\mathrm{Cu}$ concentrations in the nutrient solution.

\section{Discussion}

Cell division and elongation processes are often inhibited in plants grown in Cu-contaminated environments (Dey et al., 2014; Tiecher et al., 2018). The inhibition of these processes was evident in both plants investigated in the current study (Figures $2 \mathrm{a}, \mathrm{b}, \mathrm{c}$ and Figures $3 \mathrm{a}, \mathrm{b}, \mathrm{c}$ ). Beet plants were the ones mostly affected by increasing $\mathrm{Cu}$ concentrations; low plant development can also be associated with the significant decrease in root growth, which resulted from increased $\mathrm{Cu}$ content in the nutrient solution. Direct contact between plant roots and $\mathrm{Cu}$ ions found at toxic concentrations in the growth medium, as well as the long exposure of the root system to $\mathrm{Cu}$, hinder the absorption of water and of other nutrients by plants, a fact that leads to poor plant growth and development (Ambrosini et al., 2015; Cuba-Díaz et al., 2017; Flores-Cáceres et al., 2015; Liu et al., 2014; Sánchez-Pardo et al., 2014). In addition, the excessive $\mathrm{Cu}$ content in the root growth medium and the increased $\mathrm{Cu}$ contents in the cytosol lead to higher $\mathrm{OH}^{-}$radical production via Fenton and Haber-Weiss reactions (Girotto et al., 2013; Rodrigo-Moreno et al., 2013). The high concentration of $\mathrm{OH}^{-}$radicals, in its turn, enables great opening of $\mathrm{K}^{+}$efflux channels, as well as induces root elongation inhibition and possible cell collapse (Palm et al., 2017; Rodrigo-Moreno et al., 2013; Ryan et al., 2013). 
In addition to root growth, the high $\mathrm{Cu}$ concentration in the growth environments and the consequent $\mathrm{Cu}$ absorption by plants led to significant morphological changes in the roots and tuberous root of beet plants. The increased diameter and brownish color of the roots (Figure 4) was likely associated with excess of $\mathrm{Cu}$ in the root tissues, a fact that led to changes in distal regions of the root apex, as well as increased diameter in root areas presenting cortical and vascular cylinders (Ambrosini et al., 2015; Michaud et al., 2008). The larger root diameter of beet plants grown under high Cu concentration may also result from root growth inhibition caused by disturbances in endoderm differentiation and by premature cortical tissue lignification (Ambrosini et al., 2015; Kováč et al., 2018).

Unlike beet plants, cabbage root growth was not hindered by increased $\mathrm{Cu}$ concentrations in the culture medium. This response may be associated with the greater regenerative power of the cabbage root system and, mainly, with the great ability of this species to accumulate and tolerate high Cu levels in the root (Figures 3 c, e and f) (Radulescu et al., 2013).

Beet plants grown in the nutrient solution subjected to the highest $\mathrm{Cu}$ concentration presented the following trend of $\mathrm{Cu}$ concentrations in their tissues: roots > leaves $>$ tuberous root $>$ petiole, whereas cabbage plants followed the following trend: roots $>$ stem > leaves $>$ head. On the other hand, $\mathrm{Cu}$ accumulation in beet organs presented the following trend: tuberous root $>$ roots $>$ leaves. The highest $\mathrm{Cu}$ accumulation in tuberous roots was directly associated with higher biomass production (Figure $2 b$ ), whereas the highest $\mathrm{Cu}$ accumulation in the root may have resulted from higher $\mathrm{Cu}$ concentrations in it. Cabbage plant roots accumulated $60 \%$ of the $\mathrm{Cu}$ absorbed by the plant. Although $\mathrm{Cu}$ concentrations in cabbage head leaves increased as $\mathrm{Cu}$ in the nutrient solution increased, the amount of $\mathrm{Cu}$ accumulated in this organ did not significantly change (Figure $3 \mathrm{f}$ ). This outcome can be attributed to lower head growth, which was assessed through variable HDM.

The increased $\mathrm{Cu}$ retention in the root system of both plant species evidenced high Cu affinity for carboxylic groups found in cell wall. Some Cu may have been retained in the root apoplast, and it reduced Cu concentration in the symplast (Ambrosini et al., 2018, 2015; Comin et al., 2018). The increased Cu concentration in plant roots also results from intracellular production of organic acids such as citrate (Keller et al., 2015; Murphy et al., 1999), as well as of phytochelatins acting in cytosol. During the metal ion chelation process, chelated metals are sequestered and compartmentalized in the vacuole (Mourato et al., 2015) to avoid detrimental effects on cell metabolism (Jan and Parray, 2016; Tiecher et al., 2018). The preferential $\mathrm{Cu}$ accumulation in the root system is essential to prevent excessive $\mathrm{Cu}$ contents in the shoot, mainly in leaves.

Although the highest $\mathrm{Cu}$ retention was found in the root system of both vegetables, shoot organs also recorded increased Cu levels. Beet and cabbage leaves reached concentrations higher than $20 \mathrm{mg} \mathrm{Cu} \mathrm{kg}^{-1}$ dry mass (DM) when they were exposed to Cu concentrations in the nutrient solution higher than $0.27 \mathrm{mg}$ $\mathrm{L}^{-1}$ and $0.36 \mathrm{mg} \mathrm{L}^{-1}$, respectively. Cu concentrations between $15 \mathrm{mg} \mathrm{kg}^{-1}$ and $20 \mathrm{mg} \mathrm{kg}^{-1}$ of DM in leaves are referred to as limiting to the growth of Cu-sensitive plants (Kabata-Pendias, 2011). This aspect can lead to several physiological disturbances in plants, since high Cu concentrations in leaf tissues can 
affect the transport function of the membrane and of ion channels because it changes membrane properties (Janicka-Russak et al., 2008). Changes in the nutritional balance of plants exposed to high concentrations of heavy metals result from increased non-specific membrane permeability (Cambrollé et al., 2013). This aspect contributes to increased $\mathrm{Cu}$ absorption and accumulation in plant tissues (Tiecher et al., 2018), since excessive $\mathrm{Cu}$ can compete with other cations of the same valence, such as $\mathrm{Fe}$ and $\mathrm{Mg}$, in root absorption, as well as in other assimilation sites (Xu et al., 2015).

The increased $\mathrm{Cu}$ concentration in shoot organs resulted in higher peroxidase (POD) activity in the leaves of beet plants (Table 1), and in higher superoxide dismutase (SOD) activity in the leaves of cabbage plants (Table 2). High Cu contents in leaf tissues help catalyzing Haber-weiss reactions, which increase the production of reactive oxygen species (ROS) (Karimi et al., 2012; Miotto et al., 2014; Tiecher et al., 2018). Some defense genes may have induced POD and SOD expression, and increased their activity in beet and cabbage leaves, respectively, in response to excessive ROS production. Such response may differ between plant species, as well as between tissues in the same plant. (İseri et al., 2011; Passardi et al., 2005). This outcome indicates the potential of these enzymes to mitigate oxidative damages, since SOD act in superoxide $\left(\mathrm{O}_{2}{ }^{\circ}\right)$ conversion into $\mathrm{H}_{2} \mathrm{O}_{2}$ (Gill and Tuteja, 2010; You and Chan, 2015), which is often correlated to increased plant tolerance (Sharma et al., 2012). POD can directly convert $\mathrm{H}_{2} \mathrm{O}_{2}$ into $\mathrm{H}_{2} \mathrm{O}$ and $\mathrm{O}_{2}$; thus, it plays a key role in enabling responses to abiotic and biotic stress (Karuppanapandian et al., 2011; Yu et al., 2017), as well as in suppressing cell damages (Wu et al., 2014).

Normal TBARS and $\mathrm{H}_{2} \mathrm{O}_{2}$ levels were observed in the leaves of plants throughout the experimental period. This outcome has shown that the antioxidant system was efficient in controlling the antioxidant imbalance trend, which was explained by increased POD and SOD activity in beet and cabbage plants, respectively. However, maintaining homeostasis is costly to stressed plants, such distress can be expressed by the decreased dry matter yield in these plants, which indicates that the plant may have demanded energy to maintain the antioxidant system.

The tolerance of the investigated vegetables to increased $\mathrm{Cu}$ concentrations in the culture medium was evaluated based on $\mathrm{CTC}, \mathrm{TC}_{25}$ and $\mathrm{TC}_{50}$. Results indicated that cabbage plants are more tolerant than beet plants; cabbage CTC and $\mathrm{TC}_{25}$ values were at least $50 \%$ higher than values recorded for beet plants. In addition, $\mathrm{TC}_{50}$ was not reached in tuberous roots of beet plants or in any cabbage plant tissue; it may have happened because the critical concentrations exceeded the $\mathrm{Cu}$ concentrations tested in the current study. Higher cabbage tolerance may be associated with mechanisms triggered to mitigate damages resulting from excessive $\mathrm{Cu}$ contents in the plant culture medium. Among these mechanisms one finds $\mathrm{Cu}$ complexation/chelation and subsequent compartmentalization in the cell vacuole (Mourato et al. 2015), as well as the action of antioxidant enzymes (Karimi et al., 2012; Miotto et al., 2014).

It is possible estimating the daily $\mathrm{Cu}$ intake based on the consumption of such vegetable if one takes into consideration the $\mathrm{Cu}$ accumulation trends presented by cabbage plants, the decreased biomass production of tuberous roots and cabbage heads, as well as the $\mathrm{Cu}$ contents found in these tissues. Therefore, based on a daily per capita intake of 50 grams of each vegetable in separate, and by 
comparing the recommended daily $\mathrm{Cu}$ intake (RDI) for adult individuals - which is $0.9 \mathrm{mg}$ in Brazil (Brasil, 2005) and in the USA (FDA 2001) -, it is possible stating that tuberous roots of beet plants grown in nutrient solution subjected to Cu concentration of $1.5 \mathrm{mg} \mathrm{L}^{-1}$ account for $23 \%$ of the RDI, whereas the intake of cabbage heads of plants grown in nutrient solution subjected to $\mathrm{Cu}$ concentration of $2.52 \mathrm{mg} \mathrm{L}^{-}$ ${ }^{1}$ represent approximately $16.5 \%$ of the RDI.

\section{Conclusion}

Beet and cabbage plants accumulated $\mathrm{Cu}$, mainly that absorbed by the roots; however, increased $\mathrm{Cu}$ concentrations in the culture medium have increased the $\mathrm{Cu}$ content in the leaves, petioles and tuberous roots of beet plants, as well as in the leaves, head and stem of cabbage plants. Both plant species have shown changes in antioxidant enzyme activity, a fact that may have prevented the progress of deleterious effects on the other evaluated parameters, although it may have drained plant energy, a fact that resulted in reduced plant growth. With respect to plant organs often consumed in human diets, the decreased tuberous root growth in beet plants was more significant than that recorded for cabbage head. In addition, $\mathrm{Cu}$ contents in cabbage head remained below the values observed in the tuberous root of beet plants. Therefore, growing cabbage plants in areas contaminated with $\mathrm{Cu}$ is more viable than growing beet plants in them; besides, consuming these cabbage plants represents lesser risk to food security. However, fresh vegetables grown in Cu-enriched environments should be consumed with caution.

\section{Declarations}

\section{Ethics approval and consent to participate}

Not applicable

\section{Consent for publication}

Not applicable

\section{Availability of data and materials}

The datasets used and/or analysed during the current study are available from the corresponding author on reasonable request.

\section{Competing interests}

The authors declare that they have no competing interests. 


\section{Funding}

Conselho Nacional de Desenvolvimento Científico e Tecnológico (Brazilian National Council for Scientific and Technological Development) - CNPq, has granted a Research Productivity scholarship to the second author.

\section{Authors' contributions}

O.J. Schmitt, J.L. Andriolo, F.T. Nicoloso and G. Brunetto have designed the experiments.

J. Schmitt, M.A. Kreutz, C.R. Casagrande and T. Chassot have performed and monitored the experiments on a daily basis.

G.L. Drescher, C.R. Casagrande and C.P. Tarouco have collected and prepared the samples, as well as performed chemical and biochemical analyses on the collected tissues.

O.J. Schmitt, T. Chassot, G.L. Drescher and C.R. Lourenzi have tabulated the data, performed the statistical analyses and prepared tables and figures.

O.J. Schmitt, J.L. Andriolo, I.C.B. Silva, T.L. Tiecher and C. Marchezan have interpreted the results and wrote the manuscript.

J.L. Andriolo, F.T. Nicoloso and G. Brunetto have thoroughly reviewed the manuscript. All authors have critically reviewed the manuscript and approved the final version.

\section{Acknowledgements}

We are grateful to Conselho Nacional de Desenvolvimento Científico e Tecnológico (Brazilian National Council for Scientific and Technological Development)-CNPq for the research productivity scholarship, granted to the second author.

\section{References}

1. Adrees, M., Ali, S., Rizwan, M., Ibrahim, M., Abbas, F., Farid, M., Zia-ur-Rehman, M., Irshad, M.K., Bharwana, S.A., 2015. The effect of excess copper on growth and physiology of important food crops: a review. Environ. Sci. Pollut. Res. 22, 8148-8162. https://doi.org/10.1007/s11356-015-44965

2. Ali, S., Shahbaz, M., Shahzad, A.N., Khan, H.A.A., Anees, M., Haider, M.S., Fatima, A., 2015. Impact of copper toxicity on stone-head cabbage (Brassica oleracea var. capitata) in hydroponics. PeerJ 3, e1119. https://doi.org/10.7717/peerj.1119 
3. Ambrosini, V.G., Rosa, D.J., Bastos de Melo, G.W., Zalamena, J., Cella, C., Simão, D.G., Souza da Silva, L., Pessoa dos Santos, H., Toselli, M., Tiecher, T.L., Brunetto, G., 2018. High copper content in vineyard soils promotes modifications in photosynthetic parameters and morphological changes in the root system of 'Red Niagara' plantlets. Plant Physiol. Biochem. 128, 89-98. https://doi.org/10.1016/J.PLAPHY.2018.05.011

4. Ambrosini, V.G., Rosa, D.J., Corredor Prado, J.P., Borghezan, M., Bastos de Melo, G.W., Fonsêca de Sousa Soares, C.R., Comin, J.J., Simão, D.G., Brunetto, G., 2015. Reduction of copper phytotoxicity by liming: A study of the root anatomy of young vines (Vitis labrusca L.). Plant Physiol. Biochem. 96, 270-280. https://doi.org/10.1016/j.plaphy.2015.08.012

5. Belhaj, D., Jerbi, B., Medhioub, M., Zhou, J., Kallel, M., Ayadi, H., 2016. Impact of treated urban wastewater for reuse in agriculture on crop response and soil ecotoxicity. Environ. Sci. Pollut. Res. 23, 15877-15887. https://doi.org/10.1007/s11356-015-5672-3

6. Bicalho da Silva, I.C., Tiecher, T.L., Schneider, J.M., Trentin, E., De Conti, L., Ferreira, P.A.A., Ceretta, C.A., Araújo, M.M., Tarouco, C.P., Garlet, L.P., Hammerschmitt, R.K., Brunetto, G., 2018. Growth, biochemical response and nutritional status of Angico-Vermelho ( Parapiptadenia rigida (Bentham) Brenan) under the application of soil amendment in Cu-contaminated soil. Int. J. Phytoremediation 20, 1380-1388. https://doi.org/10.1080/15226514.2018.1474438

7. Brasil, A.N. de V.S.-A., 2005. Regulamento técnico sobre a ingestão diária recomendada (idr) de proteína, vitaminas e minerais. Brasil.

8. Brunetto, G., Wellington, G., Melo, B. De, Terzano, R., Del, D., Astol, S., Tomasi, N., Pii, Y., Mimmo, T., Cesco, S., 2016. Chemosphere Copper accumulation in vineyard soils: Rhizosphere processes and agronomic practices to limit its toxicity $162,293-307$. https://doi.org/10.1016/j.chemosphere.2016.07.104

9. Cambrollé, J., García, J.L., Figueroa, M.E., Cantos, M., 2015. Chemosphere Evaluating wild grapevine tolerance to copper toxicity 120, 171-178. https://doi.org/10.1016/j.chemosphere.2014.06.044

10. Cambrollé, J., García, J.L., Ocete, R., Figueroa, M.E., Cantos, M., 2013. Growth and photosynthetic responses to copper in wild grapevine. Chemosphere 93, 294-301.

https://doi.org/10.1016/J.CHEMOSPHERE.2013.04.080

11. Cesar Da, F., Técnico, S.E., 2009. Empresa Brasileira de Pesquisa Agropecuária Embrapa Solos Embrapa Informática Agropecuária Ministério da Agricultura, Pecuária e Abastecimento $2^{\mathrm{a}}$ edição revista e ampliada.

12. Comin, J.J., Ambrosini, V.G., Rosa, D.J., Basso, A., Loss, A., Melo, G.W.B. de, Lovato, P.E., Lourenzi, C.R., Ricachenevsky, F.K., Brunetto, G., Comin, J.J., Ambrosini, V.G., Rosa, D.J., Basso, A., Loss, A., Melo, G.W.B. de, Lovato, P.E., Lourenzi, C.R., Ricachenevsky, F.K., Brunetto, G., 2018. Liming as a means of reducing copper toxicity in black oats. Ciência Rural 48. https://doi.org/10.1590/01038478 cr20170278

13. Cuba-Díaz, M., Marín, C., Castel, K., Machuca, Á., Rifo, S., 2017. Effect of copper (II) ions on morphophysiological and biochemical variables in Colobanthus quitensis 430 Cuba-Díaz et al. J. Soil Sci. 
Plant Nutr. 17, 429-440.

14. Cui, X., Sun, X., Hu, P., Yuan, C., Luo, Y., Wu, L., Christie, P., 2015. Concentrations of Heavy Metals in Suburban Horticultural Soils and Their Uptake by Artemisia selengensis. Pedosphere 25, 878-887. https://doi.org/10.1016/S1002-0160(15)30068-0

15. De Conti, L., Ceretta, C.A., Ferreira, P.A.A., Lourenzi, C.R., Girotto, E., Lorensini, F., Tiecher, T.L., Marchezan, C., Anchieta, M.G., Brunetto, G., 2016. Soil solution concentrations and chemical species of copper and zinc in a soil with a history of pig slurry application and plant cultivation. Agric. Ecosyst. Environ. 216, 374-386. https://doi.org/10.1016/J.AGEE.2015.09.040

16. De Vos, C.H.R., Schat, H., Vooijs, R., Ernst, W.H.O., 1989. Copper-induced Damage to the Permeability Barrier in Roots of Silene cucubalus. J. Plant Physiol. 135, 164-169. https://doi.org/10.1016/S01761617(89)80171-3

17. Dey, S., Mazumder, P.B., Paul, S.B., 2014. Effect of copper on growth and chlorophyll content in tea plants (Camellia sinensis (I.) O. Kuntze) 2, 223-230.

18. Ding, Z., Li, Y., Sun, Q., Zhang, H., Ding, Z., Li, Y., Sun, Q., Zhang, H., 2018. Trace Elements in Soils and Selected Agricultural Plants in the Tongling Mining Area of China. Int. J. Environ. Res. Public Health 15, 202. https://doi.org/10.3390/ijerph15020202

19. El-moshaty, F.I.B., Pike, S.M., Novacky, A.J., Sehgal, O.P., 1993. Lipid peroxidation and superoxide production in cowpea (Vigna unguiculata) leaves infected with tobacco ringspot virus or southern bean mosaic virus. Physiol. Mol. Plant Pathol. 43, 109-119.

https://doi.org/10.1006/PMPP.1993.1044

20. FDA (Food and Drug Administration), 2001. Dietary Reference Intakesfor Vitamin A, Vitamin K, Arsenic, Boron, Chromium, Copper, lodine, Iron, Manganese, Molybdenum, Nickel, Silicon, Vanadium,and Zinc [WWW Document]. Cent. Food Saf. Appl. Nutr. URL https://s3.amazonaws.com/public-inspection.federalregister.gov/2016-11867.pdf (accessed 7.1.19).

21. Filgueira, F.A.R., 2012. Novo manual de olericultura: agrotecnologia moderna na produção e comercialização de hortaliças, UFV. ed. Viçosa.

22. Flores-Cáceres, M.L., Hattab, Sabrine, Hattab, Sarra, Boussetta, H., Banni, M., Hernández, L.E., 2015. Specific mechanisms of tolerance to copper and cadmium are compromised by a limited concentration of glutathione in alfalfa plants. Plant Sci. 233, 165-173.

https://doi.org/10.1016/J.PLANTSCI.2015.01.013

23. Giannopolitis, C.N., Ries, S.K., 1977. Superoxide Dismutases: II. Purification and Quantitative Relationship with Water-soluble Protein in Seedlings. Plant Physiol. 59, 315-8. https://doi.org/10.1104/pp.59.2.315

24. Gill, S.S., Tuteja, N., 2010. Reactive oxygen species and antioxidant machinery in abiotic stress tolerance in crop plants. Plant Physiol. Biochem. 48, 909-930.

https://doi.org/10.1016/j.plaphy.2010.08.016

25. Girotto, E., Ceretta, C.A., Rossato, L. V., Farias, J.G., Tiecher, T.L., De Conti, L., Schmatz, R., Brunetto, G., Schetinger, M.R.C., Nicoloso, F.T., 2013. Triggered antioxidant defense mechanism in maize grown in 
soil with accumulation of $\mathrm{Cu}$ and $\mathrm{Zn}$ due to intensive application of pig slurry. Ecotoxicol. Environ. Saf. 93, 145-155. https://doi.org/10.1016/J.ECOENV.2013.03.021

26. Hiscox, J.D., Israelstam, G.F., 1979. A method for the extraction of chlorophyll from leaf tissue without maceration. Can. J. Bot. 57, 1332-1334. https://doi.org/10.1139/b79-163

27. Hu, W., Huang, B., Tian, K., Holm, P.E., Zhang, Y., 2017. Heavy metals in intensive greenhouse vegetable production systems along Yellow Sea of China: Levels, transfer and health risk. Chemosphere 167, 82-90. https://doi.org/10.1016/j.chemosphere.2016.09.122

28. İşeri, Ö.D., Körpe, D.A., Yurtcu, E., Sahin, F.I., Haberal, M., 2011. Copper-induced oxidative damage, antioxidant response and genotoxicity in Lycopersicum esculentum Mill. and Cucumis sativus $\mathrm{L}$. Plant Cell Rep. 30, 1713-1721. https://doi.org/10.1007/s00299-011-1079-x

29. Jan, S., Parray, J.A., 2016. Heavy Metal Uptake in Plants, in: Approaches to Heavy Metal Tolerance in Plants. Springer Singapore, Singapore, pp. 1-18. https://doi.org/10.1007/978-981-10-1693-6_1

30. Janicka-Russak, M., Kabała, K., Burzyński, M., Kłobus, G., 2008. Response of plasma membrane H+ATPase to heavy metal stress in Cucumis sativus roots. J. Exp. Bot. 59, 3721-8. https://doi.org/10.1093/jxb/ern219

31. Kabata-Pendias, A., 2011. Trace elements in soils and plants. CRC Press. Boca Ratón, Florida.

32. Karimi, P., Khavari-Nejad, R.A., Niknam, V., Ghahremaninejad, F., Najafi, F., 2012. The effects of excess copper on antioxidative enzymes, lipid peroxidation, proline, chlorophyll, and concentration of $\mathrm{Mn}, \mathrm{Fe}$, and $\mathrm{Cu}$ in Astragalus neo-mobayenii. ScientificWorldJournal. 2012, 615670. https://doi.org/10.1100/2012/615670

33. Karuppanapandian, T., Moon, J.-C., Kim, C., Manoharan, K., Kim, W., 2011. Reactive Oxygen Species in Plants: Their Generation, Signal Transduction, and Scavenging Mechanisms. Aust. J. Crop Sci. 5, 709-725.

34. Keller, C., Rizwan, M., Davidian, J.-C., Pokrovsky, O.S., Bovet, N., Chaurand, P., Meunier, J.-D., 2015. Effect of silicon on wheat seedlings (Triticum turgidum L.) grown in hydroponics and exposed to 0 to 30 M Cu. Planta 241, 847-860. https://doi.org/10.1007/s00425-014-2220-1

35. Kopsell, D.E., Kopsell, D.A., 2007. Copper, in: Barker, A.V., Pilbeam, D.J. (Eds.), Handbook of Plant Nutrition. Taylor and Francis Group, Boca Raton, pp. 293-328.

36. Kováč, J., Lux, A., Vaculík, M., 2018. Formation of a subero-lignified apical deposit in root tip of radish (Raphanus sativus) as a response to copper stress. Ann. Bot. 122, 823-831. https://doi.org/10.1093/aob/mcy013

37. Lequeux, H., Hermans, C., Lutts, S., Verbruggen, N., 2010. Response to copper excess in Arabidopsis thaliana: Impact on the root system architecture, hormone distribution, lignin accumulation and mineral profile. Plant Physiol. Biochem. 48, 673-682.

https://doi.org/10.1016/J.PLAPHY.2010.05.005

38. Lichtenthaler, H.K., 1987. Chlorophylls and carotenoids: Pigments of photosynthetic biomembranes. Methods Enzymol. 148, 350-382. https://doi.org/10.1016/0076-6879(87)48036-1 
39. Liu, J.J., Wei, Z., Li, J.H., 2014. Effects of copper on leaf membrane structure and root activity of maize seedling. Bot. Stud. 55, 47. https://doi.org/10.1186/s40529-014-0047-5

40. Loreto, F., Velikova, V., 2001. Isoprene produced by leaves protects the photosynthetic apparatus against ozone damage, quenches ozone products, and reduces lipid peroxidation of cellular membranes. Plant Physiol. 127, 1781-7.

41. Marschner, H., Marschner, P., 2012. Mineral nutrition of higher plants. Academic Press.

42. Mateos-Naranjo, E., Andrades-Moreno, L., Cambrollé, J., Perez-Martin, A., 2013. Assessing the effect of copper on growth, copper accumulation and physiological responses of grazing species Atriplex halimus: Ecotoxicological implications. Ecotoxicol. Environ. Saf. 90, 136-142.

https://doi.org/10.1016/j.ecoenv.2012.12.020

43. Michaud, A.M., Chappellaz, C., Hinsinger, P., 2008. Copper phytotoxicity affects root elongation and iron nutrition in durum wheat (Triticum turgidum durum L.). Plant Soil 310, 151-165. https://doi.org/10.1007/s11104-008-9642-0

44. Miotto, A.., Ceretta, C.A.., Girotto, E.., Trentin, G.., Kaminski, J.., De Conti, L.., T.; M., Elena, B.., Brunetto, G., 2017. Copper Accumulation and Availability in Sandy, Acid, Vineyard Soils. Commun. Soil Sci. Plant Anal. 48, 1167-1183.

45. Miotto, A., Ceretta, C.A., Brunetto, G., Nicoloso, F.T., Girotto, E., Farias, J.G., Tiecher, T.L., De Conti, L., Trentin, G., 2014. Copper uptake, accumulation and physiological changes in adult grapevines in response to excess copper in soil. Plant Soil 374, 593-610. https://doi.org/10.1007/s11104-0131886-7

46. Morales, J.M.L., Rodríguez-Monroy, M., Sepúlveda-Jiménez, G., 2012. Betacyanin accumulation and guaiacol peroxidase activity in Beta vulgaris L. leaves following copper stress. Acta Soc. Bot. Pol. 81, 193-201. https://doi.org/10.5586/asbp.2012.019

47. Mourato, M.P., Moreira, I.N., Leitão, I., Pinto, F.R., Sales, J.R., Martins, L.L., 2015. Effect of Heavy Metals in Plants of the Genus Brassica. Int. J. Mol. Sci. 16, 17975-98. https://doi.org/10.3390/ijms160817975

48. Murphy, A.S., Eisinger, W.R., Shaff, J.E., Kochian, L. V, Taiz, L., 1999. Early copper-induced leakage of $\mathrm{K}(+)$ from Arabidopsis seedlings is mediated by ion channels and coupled to citrate efflux. Plant Physiol. 121, 1375-82. https://doi.org/10.1104/pp.121.4.1375

49. Palm, E., Guidi Nissim, W., Giordano, C., Mancuso, S., Azzarello, E., 2017. Root potassium and hydrogen flux rates as potential indicators of plant response to zinc, copper and nickel stress. Environ. Exp. Bot. 143, 38-50. https://doi.org/10.1016/J.ENVEXPBOT.2017.08.009

50. Pan, X.-D., Wu, P.-G., Jiang, X.-G., 2016. Levels and potential health risk of heavy metals in marketed vegetables in Zhejiang, China. Sci. Rep. 6, 20317. https://doi.org/10.1038/srep20317

51. Passardi, F., Cosio, C., Penel, C., Dunand, C., 2005. Peroxidases have more functions than a Swiss army knife. Plant Cell Rep. 24, 255-265. https://doi.org/10.1007/s00299-005-0972-6

52. Radulescu, C., Stihi, C., Popescu, I. V, Dulama, I.D., Chelarescu, E.D., Chilian, A., 2013. Heavy metal accumulation and translocation in different parts of Brassica oleracea L. Rom. J. Phys. 58, 1337- 
1354.

53. Rodrigo-Moreno, A., Andrés-Colás, N., Poschenrieder, C., Gunsé, B., Peñarrubia, L., Shabala, S., 2013. Calcium- and potassium-permeable plasma membrane transporters are activated by copper in Arabidopsis root tips: linking copper transport with cytosolic hydroxyl radical production. Plant. Cell Environ. 36, 844-855. https://doi.org/10.1111/pce.12020

54. Ryan, B.M., Kirby, J.K., Degryse, F., Harris, H., Mclaughlin, M.J., Scheiderich, K., Ryan, B., 2013. Copper speciation and isotopic fractionation in plants: uptake and translocation mechanisms. New Phytol. 199, 367-378. https://doi.org/10.1111/nph.12276

55. Sánchez-Pardo, B., Fernández-Pascual, M., Zornoza, P., 2014. Copper microlocalisation and changes in leaf morphology, chloroplast ultrastructure and antioxidative response in white lupin and soybean grown in copper excess. J. Plant Res. 127, 119-129. https://doi.org/10.1007/s10265-013-0583-1

56. Sharma, P., Jha, A.B., Dubey, R.S., Pessarakli, M., 2012. Reactive Oxygen Species, Oxidative Damage, and Antioxidative Defense Mechanism in Plants under Stressful Conditions. J. Bot. 2012, 1-26. https://doi.org/10.1155/2012/217037

57. Sun, F.F., Wang, F.H., Wang, X., He, W., Wen, D., Wang, Q.F., Liu, X.X., 2013. Soil threshold values of total and available cadmium for vegetable growing based on field data in Guangdong province, South China. J. Sci. Food Agric. 93, 1967-1973. https://doi.org/10.1002/jsfa.6000

58. Tazzo, I.F., Heldwein, A.B., Maldaner, I.C., Pivetta, C.R., Streck, L., Righi, E.Z., 2012. Evapotranspiração do pimentão em estufa plástica estimada com dados meteorológicos externos, na primavera. Rev. Bras. Eng. Agrícola e Ambient. 16, 275-280. https://doi.org/10.1590/S1415-43662012000300007

59. Tiecher, T.L., Soriani, H.H., Tiecher, T., Ceretta, C.A., Nicoloso, F.T., Tarouco, C.P., Clasen, B.E., De Conti, L., Tassinari, A., Melo, G.W.B., Brunetto, G., 2018. The interaction of high copper and zinc doses in acid soil changes the physiological state and development of the root system in young grapevines (Vitis vinifera). Ecotoxicol. Environ. Saf. 148, 985-994. https://doi.org/10.1016/J.ECOENV.2017.11.074

60. Trentin, E., Facco, D.B., Hammerschmitt, R.K., Avelar Ferreira, P.A., Morsch, L., Belles, S.W., Ricachenevsky, F.K., Nicoloso, F.T., Ceretta, C.A., Tiecher, T.L., Tarouco, C.P., Berghetti, Á.L.P., Toselli, M., Brunetto, G., 2019. Potential of vermicompost and limestone in reducing copper toxicity in young grapevines grown in Cu-contaminated vineyard soil. Chemosphere 226, 421-430. https://doi.org/10.1016/j.chemosphere.2019.03.141

61. Wu, W., Wan, X., Shah, F., Fahad, S., Huang, J., 2014. The role of antioxidant enzymes in adaptive responses to sheath blight infestation under different fertilization rates and hill densities. ScientificWorldJournal. 2014, 502134. https://doi.org/10.1155/2014/502134

62. Xu, X., Xu, Y., Chi, Y., Wang, P., Shi, G., Xu, X.Y., 2015. Changes of Essential Mineral Elements Contents in Response to $\mathrm{Cu} 2+$ Treatment in Sagittaria sagittifolia. J. Environ. Prot. (Irvine,. Calif). 6, 700-709. https://doi.org/10.4236/jep.2015.67063

63. Yang, X., Li, Q., Tang, Z., Zhang, W., Yu, G., Shen, Q., Zhao, F.-J., 2017. Heavy metal concentrations and arsenic speciation in animal manure composts in China. Waste Manag. 64, 333-339. 
https://doi.org/10.1016/J.WASMAN.2017.03.015

64. You, J., Chan, Z., 2015. ROS Regulation During Abiotic Stress Responses in Crop Plants. Front. Plant Sci. 6, 1092. https://doi.org/10.3389/fpls.2015.01092

65. Yu, R., Tang, Y., Liu, C., Du, X., Miao, C., Shi, G., 2017. Comparative transcriptomic analysis reveals the roles of ROS scavenging genes in response to cadmium in two pak choi cultivars. Sci. Rep. 7, 9217. https://doi.org/10.1038/s41598-017-09838-2

66. Zeraik, A.E., Sant', F., De Souza, A., Fatibello-Filho, O., Leite, O.D., 2008. Desenvolvimento de um spot test para o monitoramento da atividade da peroxidase em um procedimento de purificação. Quim. Nov. 31, 731-734.

67. Zhu, Z., Wei, G., Li, J., Qian, Q., Yu, J., 2004. Silicon alleviates salt stress and increases antioxidant enzymes activity in leaves of salt-stressed cucumber (Cucumis sativus L.). Plant Sci. 167, 527-533. https://doi.org/10.1016/J.PLANTSCI.2004.04.020

\section{Figures}



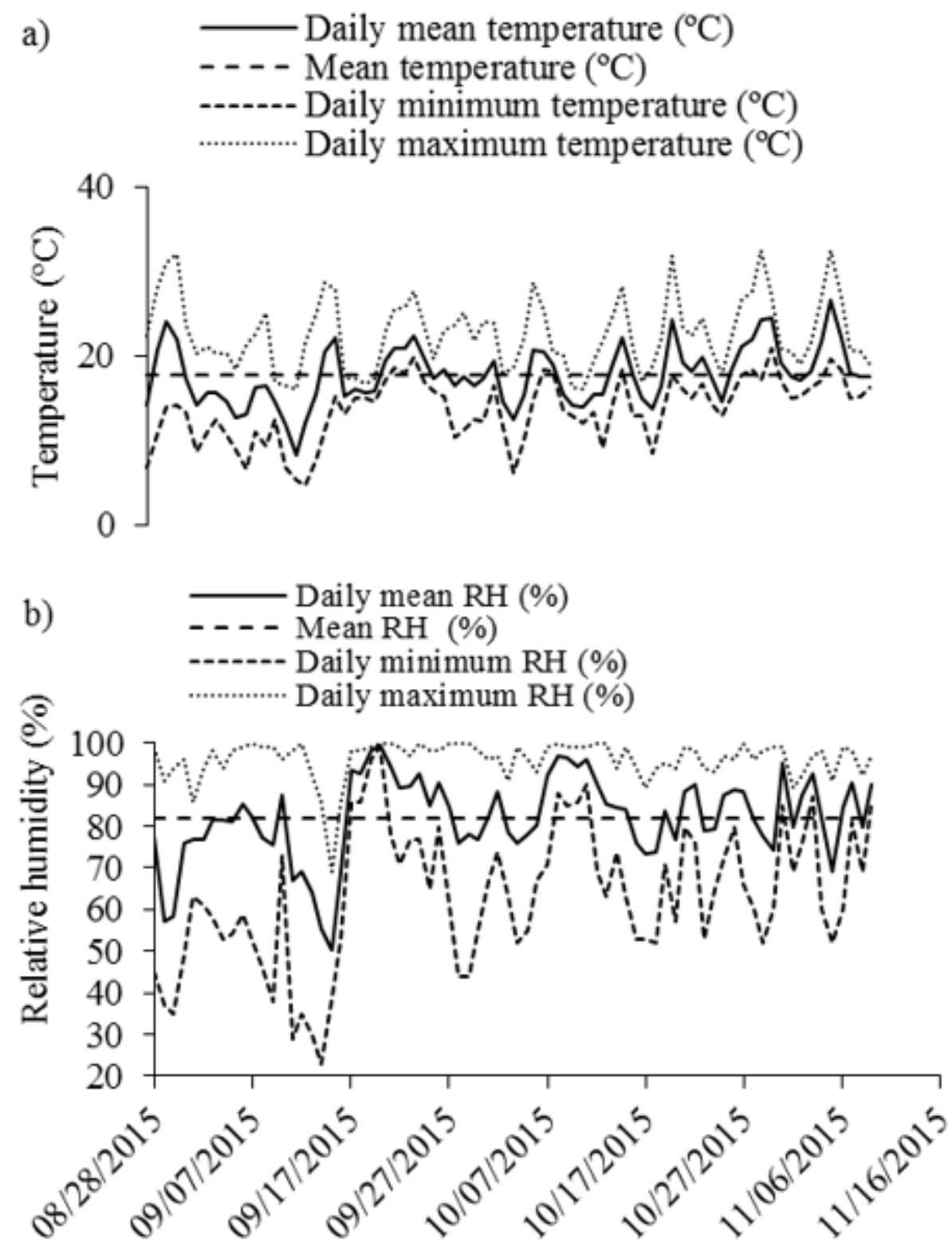

\section{Figure 1}

Data about mean air temperature (a) and relative humidity (b) in the growing environment were recorded by two electronic recorders (NOVUS, LogBox-RHT-LCD, Brazil) installed above the plants. 


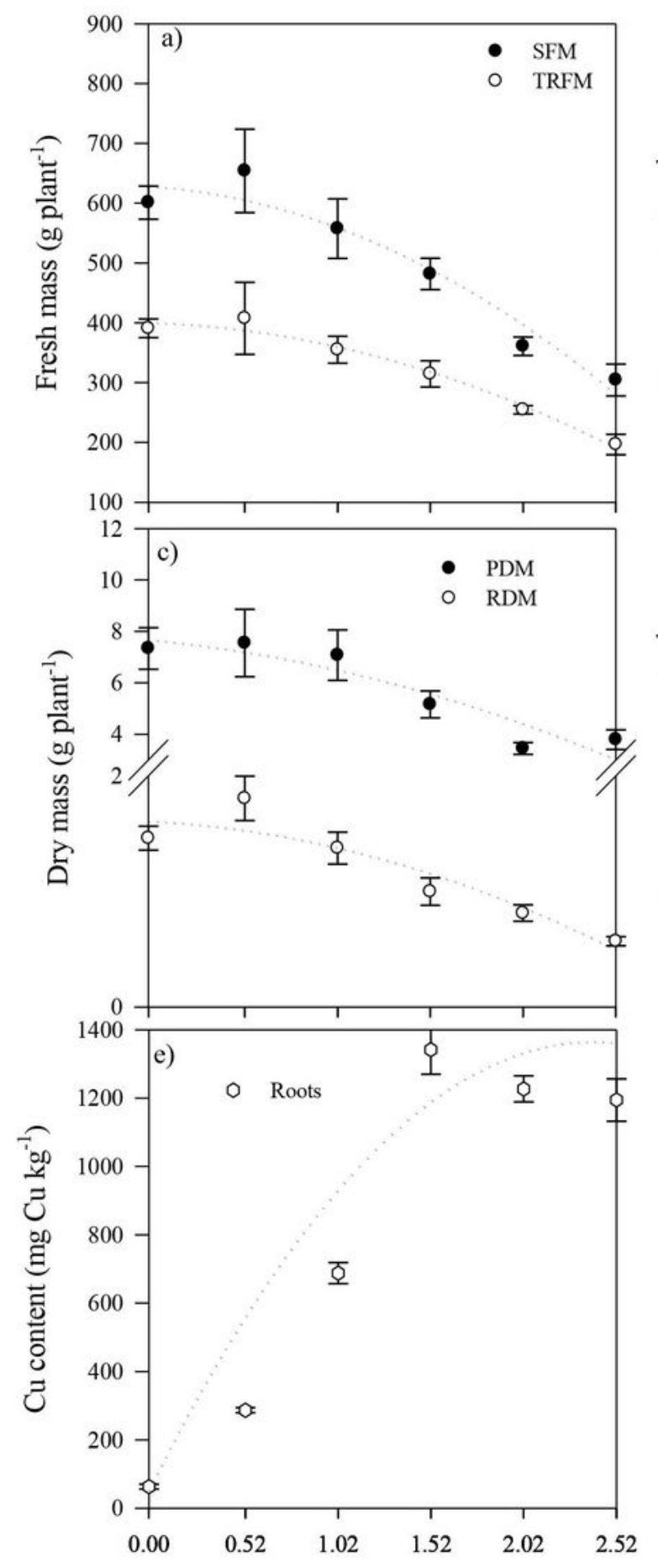

$\mathrm{Cu}$ concentration $\left(\mathrm{mg} \mathrm{L}^{-1}\right)$

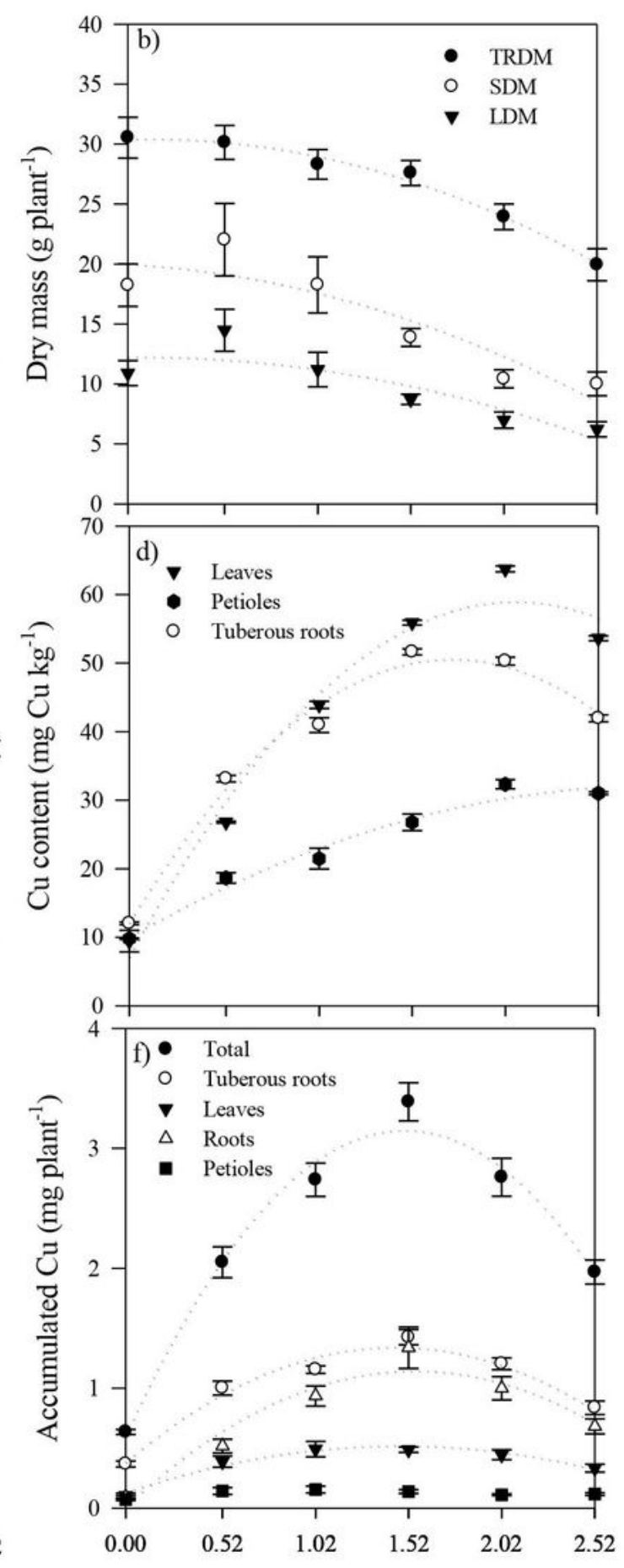

$\mathrm{Cu}$ concentration $\left(\mathrm{mg} \mathrm{L}^{-1}\right)$

\section{Figure 2}

Shoot (SFM) and tuberous root (TRFM) fresh mass (a); tuberous root (TRDM), shoot (SDM) and leaf (LDM) dry mass (b); petiole (PDM) ) and root (RDM) dry mass (c); Cu contents in different tissues (d, e); and total and accumulated $\mathrm{Cu}$ in different organs (f) of beet plants, cv. "Katrina", grown in nutrient solution subjected to different $\mathrm{Cu}$ concentrations. Vertical bars represent the standard error. 

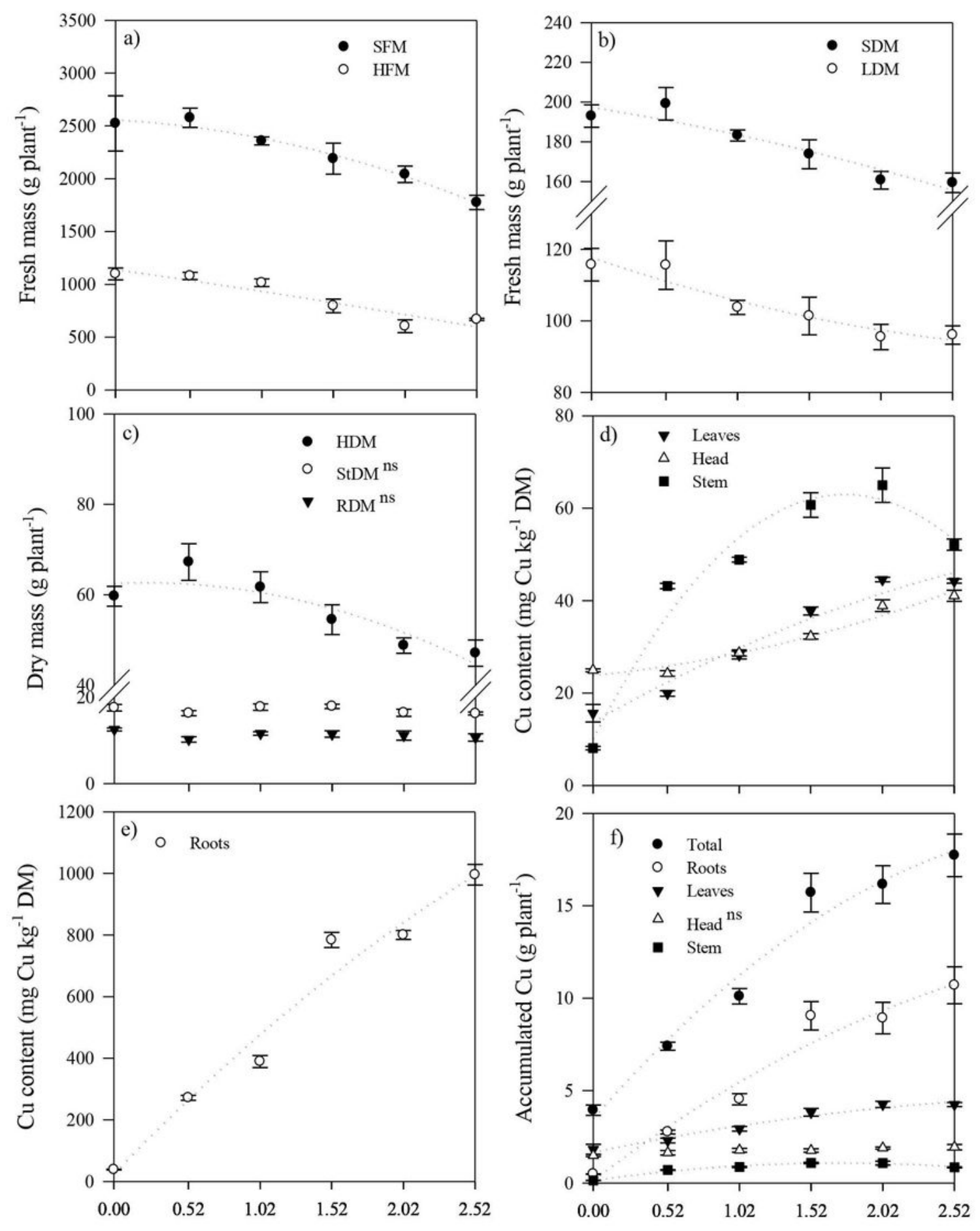

$\mathrm{Cu}$ concentration $\left(\mathrm{mg} \mathrm{L}^{-1}\right)$

$\mathrm{Cu}$ concentration $\left(\mathrm{mg} \mathrm{L}^{-1}\right)$

\section{Figure 3}

Shoot (SFM) and head (HFM) fresh mass (a); shoot (SDM) and leaf (LDM) dry mass (b); Head (HDM), Stem (StDM) and root (RDM) dry mass (c); Cu contents in different organs (d, e); and total and accumulated $\mathrm{Cu}$ contents in different organs (f) of cabbage plants, cv. "Fuyutoyo", grown in nutrient solution subjected to different $\mathrm{Cu}$ concentrations. Vertical bars represent standard error. 


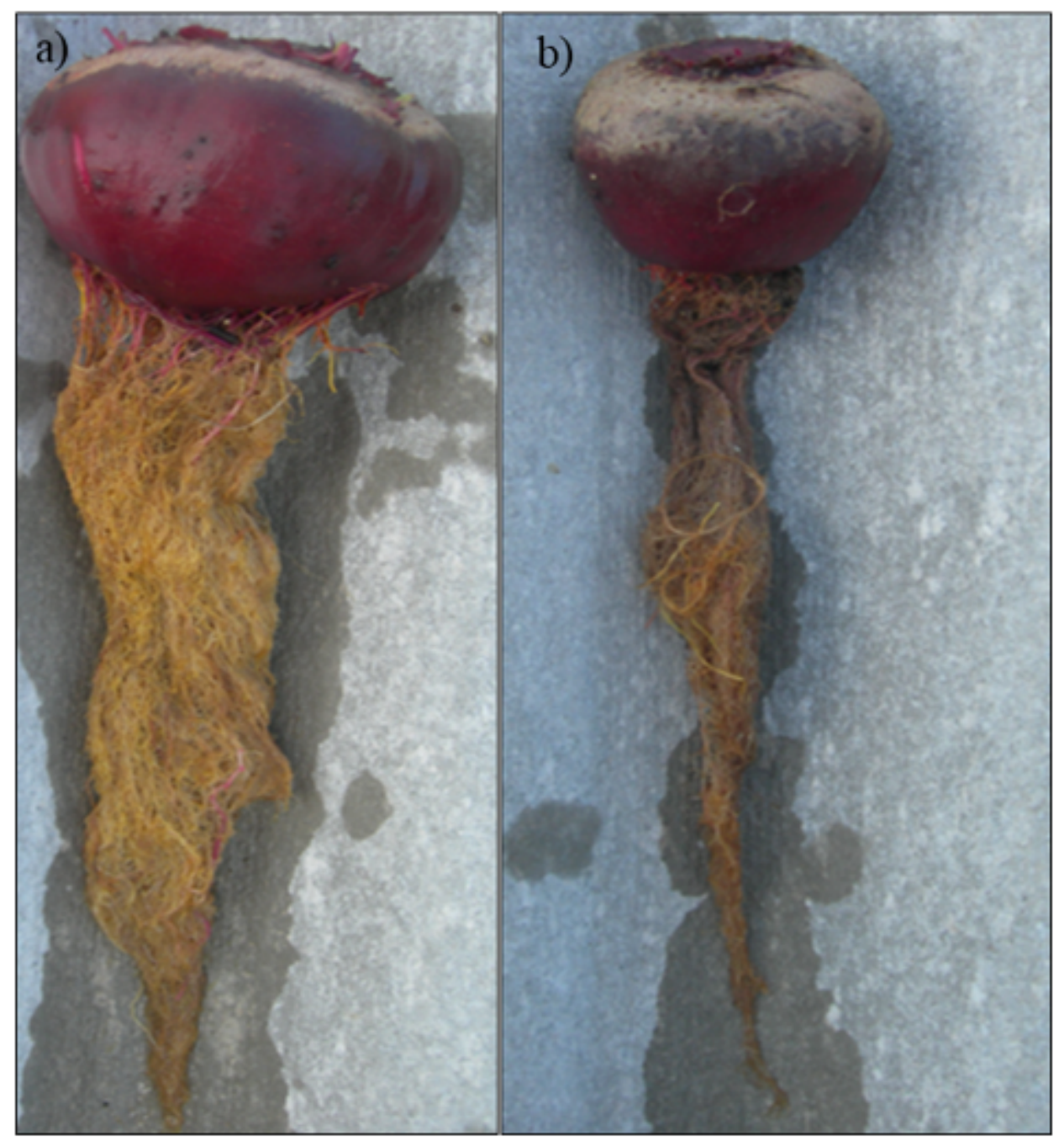

\section{Figure 4}

Tuberous roots and roots of beet plants grown in nutrient solution subjected to $\mathrm{Cu}$ concentrations of (a) $0.52 \mathrm{mg} \mathrm{L}-1$ and (b) $2.52 \mathrm{mg} \mathrm{L}-1$. 